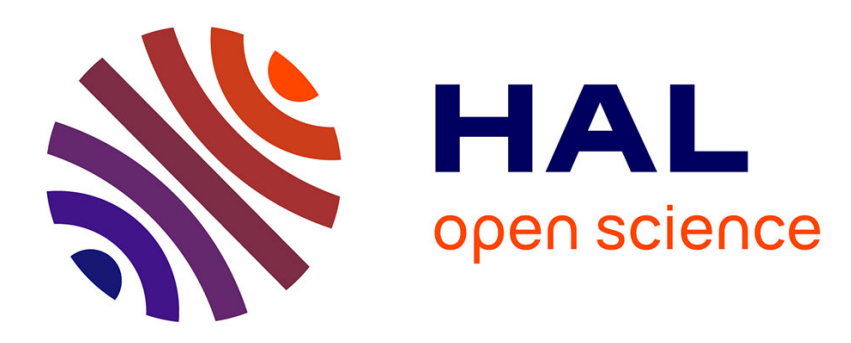

\title{
European Debt Crisis: How a Public debt Restructuring Can Solve a Private Debt issue David Cayla
}

\section{To cite this version:}

David Cayla. European Debt Crisis: How a Public debt Restructuring Can Solve a Private Debt issue. Journal of Economic Issues, 2013, 47 (2), pp.427-436. halshs-00845503

\section{HAL Id: halshs-00845503 https://shs.hal.science/halshs-00845503}

Submitted on 17 Jul 2013

HAL is a multi-disciplinary open access archive for the deposit and dissemination of scientific research documents, whether they are published or not. The documents may come from teaching and research institutions in France or abroad, or from public or private research centers.
L'archive ouverte pluridisciplinaire HAL, est destinée au dépôt et à la diffusion de documents scientifiques de niveau recherche, publiés ou non, émanant des établissements d'enseignement et de recherche français ou étrangers, des laboratoires publics ou privés. 


\title{
European Debt Crisis: How a Public Debt Restructuring \\ Can Solve a Private Debt Issue
}

David Cayla ${ }^{a}$

\begin{abstract}
The political and economic crisis in Europe is often viewed as an indirect consequence of the global financial and economic breakdowns caused by the US "subprime" crisis. European governments themselves tend to underestimate Europe's responsibility for the crisis and seem to prefer to manage the symptoms of the crisis rather than pursue a real recovery from it. This paper argues that the enforced policies are far from achieving an appropriate economic solution for the Eurozone. Moreover, it suggests that, although the European domestic debt situation is very close to the American one, their most recent evolutions and their main causes differ. If the growth of the American debt can partly be explained by macroeconomics imbalances, the causes of the growth of the European domestic debt must be found in a change in the behavior of the financial sector agents. The conclusion advocates for a more radical European policy to solve the debt bubble.
\end{abstract}

Keywords: european economy, financial crisis, macroeconomic imbalances, debt structure, debt bubble, macroeconomic policies

JEL Classification Codes: E20, E12, E60

\section{Introduction}

The political and economic crisis in Europe is often viewed as an indirect consequence of the global financial and economic breakdowns caused by the US imbalances in financial and trade activities as well as by the inequalities in incomes distribution. European governments themselves tend to underestimate Europe's responsibility for the crisis and seem to prefer to manage the symptoms of the crisis rather than pursue a real recovery from it. The mainstream policies implemented in Europe follow two main directions. In the short run, European authorities try to solve the sovereign-debt issues by organizing a federal financing system for the countries that are excluded from financial markets and by legally constraining the public deficits of its members. ${ }^{1}$ In the medium and long term, they try to solve the Eurozone internal imbalances by pushing southern countries into implementing the so-called pro-competitive reforms (especially in labor markets) in order to improve their trade balances. These policies are based on two beliefs: First, that the public debt is the contextual cause of the European economic difficulties, and, second, that the lack of competitiveness on the part of Southern Europe is the structural reason why these countries cannot fix their public debt issues.

a Angers University, GRANEM research center. This paper was presented at the annual meeting of the Association for Evolutionary Economics, January 4-6 2013 in San Diego, CA. I am very grateful to Alexandra Dariet for her helpful corrections. 
In this paper, I argue that these policies are far from achieving an appropriate economic solution for the Eurozone. The first section will show that, contrary to common beliefs, the European domestic debt situation is very close to the American one both in its magnitude and recent developments. Contrary to what happens in United States, however, the past months did not bring any decrease in the amount of outstanding debt. The second section will explain the reasons why I believe that the Eurozone economy, although very different from the American one, ended up into a similar economic crisis. The final section will discuss these findings and advocate for a more radical European policy to solve this debt bubble.

\section{American and European Situations: A Brief Comparison}

Although they do not always agree on its ultimate causes, most economists admit that one of the main issues of the so-called "Great Recession" rests on the American domestic debt that steadily increased in the years prior to the 2007 "subprime" mortgage crisis. Figures from the Federal Reserve show that the outstanding amounts of the American domestic debt rose from 247 percent of the U.S. GDP in 1997 to 366 percent in 2009.

Figure 1. Components of Total U.S. Domestic Debt (\% GDP) Source: Federal Reserve

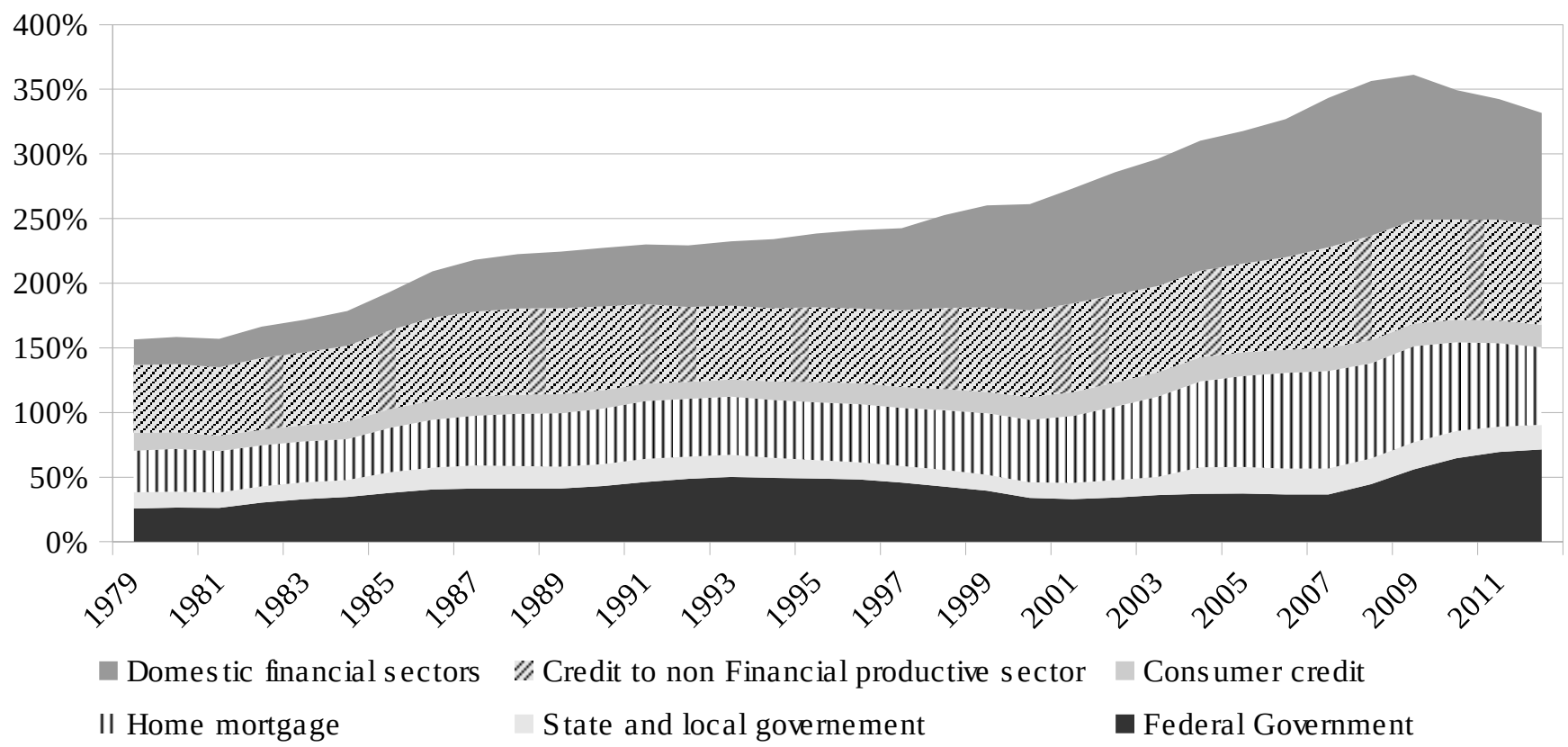

In economic literature, three main economic trends are often emphasized to explain this rapid growth of the domestic debt. First, the American current accounts imbalances and the specific role of the dollar in terms of international transactions and reserve currency pushed emerging countries (among them China) to buy American securities assets as a counterpart for their trade surpluses (Caballero and Krishnamurthy 2009; Liang 2012; Palley 2009). Second, the Federal Reserve policy of 
low interest rates, combined with the deregulation of the financial sector, increased private debts, especially in the financial and housing sectors (Guttmann and Plihon 2010). Third, bubbles in financial and non-financial assets artificially increased the value of these assets, allowing individual agents to borrow more (Rosser, Rosser and Gallegali 2012).

Although it is hard to believe that a dynamic growth will appear in the short run, it has to be noted that since its 2009 peak, the American private debt has been decreasing rapidly. Households debt, for example, fell from 91.6 to 77.43 percent of the GDP at the end of September 2012, while the liabilities of the non-financial productive sector decreased from 80.12 to 76.72 percent of the GDP. Moreover, the debt of the financial sector went through a very rapid decline during that period, from 112.41 to 87.26 percent of the GDP. As expected, the Federal government played its Keynesian role of "ultimate borrower" in order to save the economy from a severe credit crunch. As a result, the federal government's debt rose from 55.86 to 71.34 percent of the GDP. Overall, the domestic U.S. debt was almost thirty points lower at the end of September 2012 than it was two and a half years before. For the present, the result of this policy that substitutes public for private debt can be seen as fairly successful. Job losses are contained and the American economic activity is back on (a slow) track.

Across the ocean, the Eurozone is often seen as resting on a more stable private financial system, except for some housing and banking troubles in Spain and Ireland. However, figures from the European Central Bank indicate a landscape that is, in fact, identical to the American one.

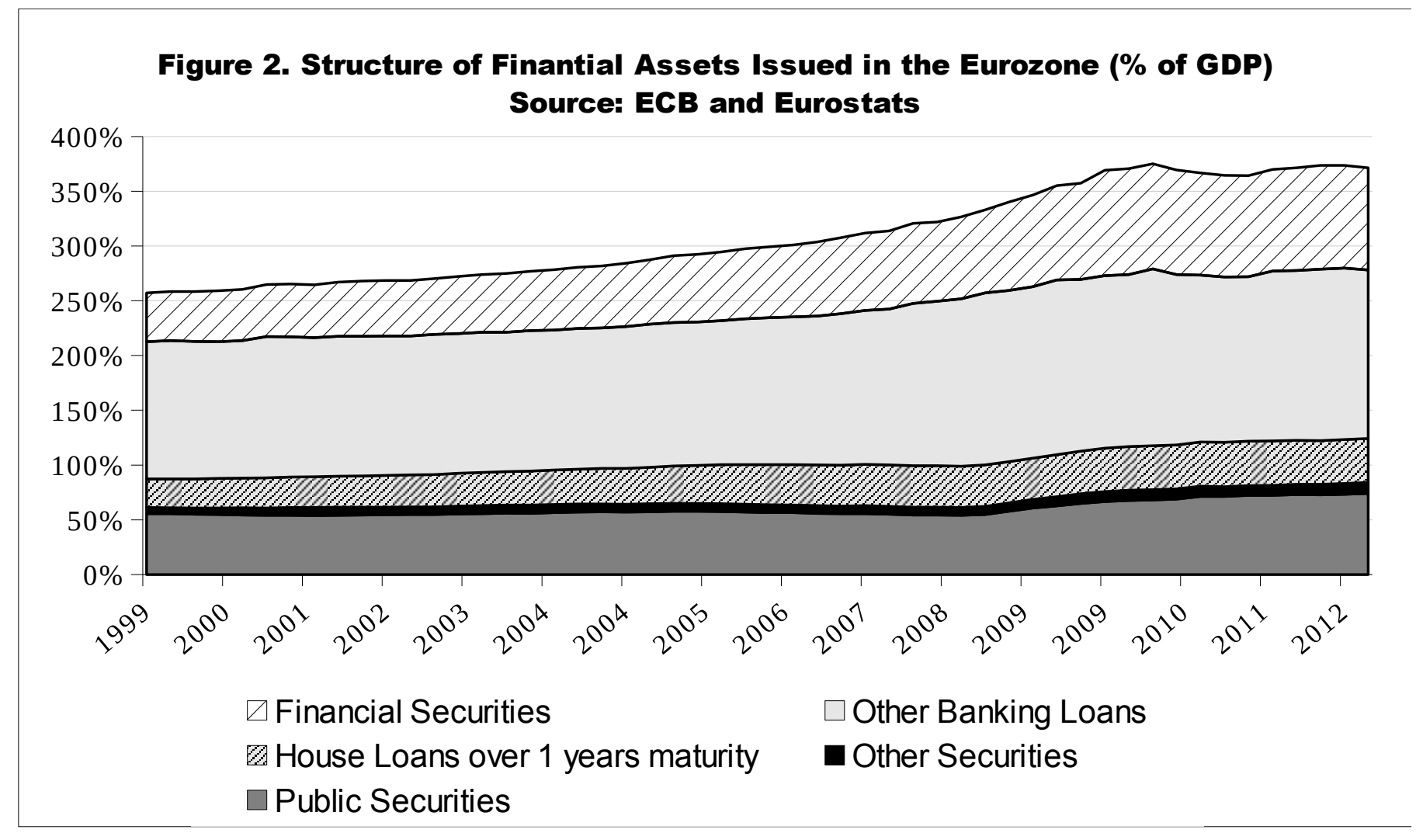


As in the American economy, the Eurozone agents have to face a steady increase of their liabilities. At the end of 1999, the Eurozone domestic outstanding debt constituted 257.14 percent of the Eurozone GDP (264.37 percent for the US) and reached its peak of 375.03 percent of the GDP in the mid-2010 (366 percent for America). However, contrary to the American situation, the level of the Eurozone domestic debt, after a small decrease in 2010-2011, has increased again over the very recent period.

Table 1. Historical Evolution of the Eurozone Debt Structure

\begin{tabular}{|c|c|c|c|c|c|}
\hline Debt origin & 1999 Q4 & 2010 Q2 & $\begin{array}{c}1999-2010 \\
\text { Evolution (\%) }\end{array}$ & 2012 Q3 & $\begin{array}{c}2010-2012 \\
\text { Evolution (\%) }\end{array}$ \\
\hline $\begin{array}{c}\text { Government } \\
\text { Securities }\end{array}$ & $55.66 \%$ & $68.26 \%$ & $+22.64 \%$ & $74.00 \%$ & $+8.41 \%$ \\
\hline $\begin{array}{c}\text { Securities from the } \\
\text { financial sector }\end{array}$ & $44.60 \%$ & $95.98 \%$ & $+115.20 \%$ & $93.17 \%$ & $-2.93 \%$ \\
\hline $\begin{array}{c}\text { Securities from other } \\
\text { sectors }\end{array}$ & $5.56 \%$ & $9.28 \%$ & $+66.91 \%$ & $10.23 \%$ & $+10.24 \%$ \\
\hline $\begin{array}{c}\text { House Loans over 1 } \\
\text { year maturity }\end{array}$ & $26.02 \%$ & $40.04 \%$ & $+53.88 \%$ & $40.11 \%$ & $+0.17 \%$ \\
\hline $\begin{array}{c}\text { Other banking loans } \\
\text { in Euros }\end{array}$ & $125.14 \%$ & $161.46 \%$ & $+29.02 \%$ & $153.82 \%$ & $-4.73 \%$ \\
\hline Total & $257.14 \%$ & $375.03 \%$ & $+45.85 \%$ & $371.32 \%$ & $-0.99 \%$ \\
\hline
\end{tabular}

Source: $E C B$

Table 1 shows that almost half of the debt growth from 1999 to 2010 in Europe can be attributed to the financial sector. Over this ten-year period, the total amount of debt securities issued by the Eurozone financial sector has more than doubled in relation to the GDP. Also, neither the housing nor the public sectors can be seen as a major cause for the global domestic debt increase.

\section{Finding the Causes of the Eurozone Debt Growth}

An increase in the ratio between the domestic debt and domestic product of an economy can have four main ramifications. First, it can be the effect of an increasing investment rate. In this case, productive agents (mostly governmental sector and non-financial firms) are willing to borrow more because they expect increasing revenues in the future. Debts increase in proportion to expected revenues and when it is compared with actual economic activity. In response to this growing credit demand from the productive sector, banks and financial markets need to increase their leverage, which explains the important growth of securities issuance from the financial sector. However, this 
explanation must be ruled out. As Figure 3 shows, investment expenditures in the Eurozone tended to decline over the 1999-2010 period and did not seem related to the evolution of the domestic debt.

Figure 3. Gross Fixed Capital Formation in the Eurozone (\% of GDP) Source: Eurostat

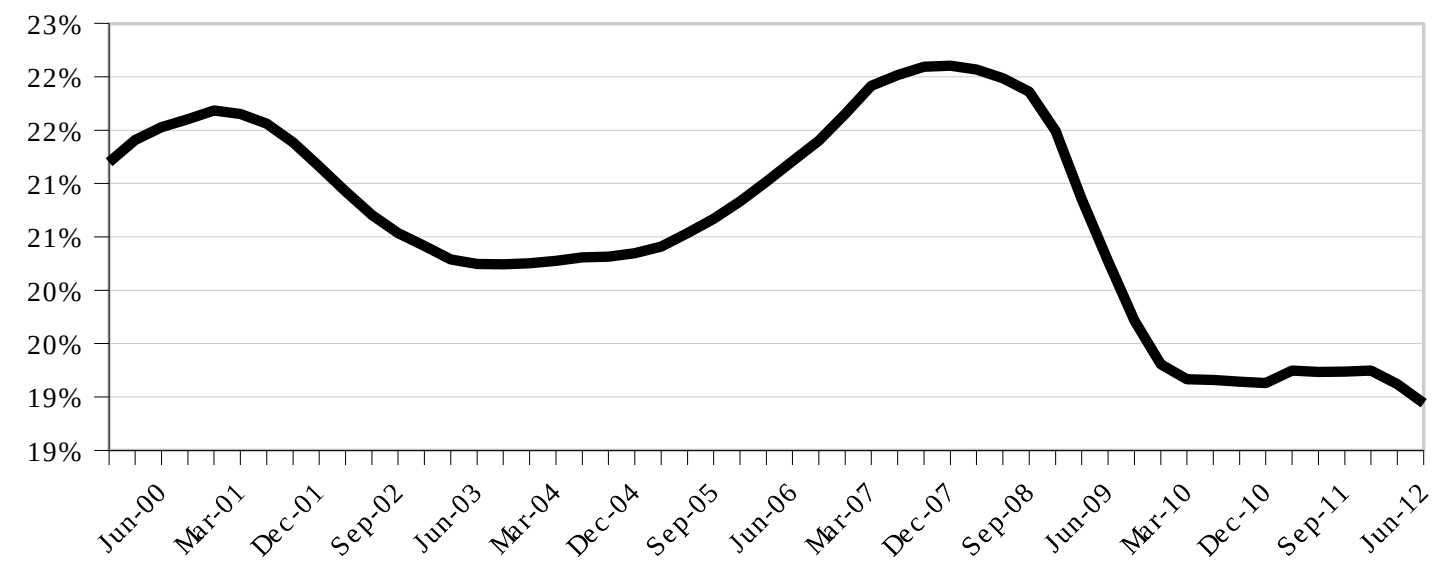

Second, the growth of the domestic debt in proportion to the GDP may be explained by the external imbalances. In order to stabilize their financial position and to increase their foreign-exchange reserves, emerging economic powers such as Brazil and China must buy securities issued in developed countries in proportion to their economic growth (Liang 2012). Because their economic growth rate is higher than the growth rate of the securities issuers, an increase of the ratio debt-toGDP has occurred in developed countries, as well as an imbalance in their current accounts. This explanation fits fairly well with the American situation as mentioned earlier. However, Figure 4 shows that it is not the case for the Eurozone since there are no structural imbalances in its current accounts.

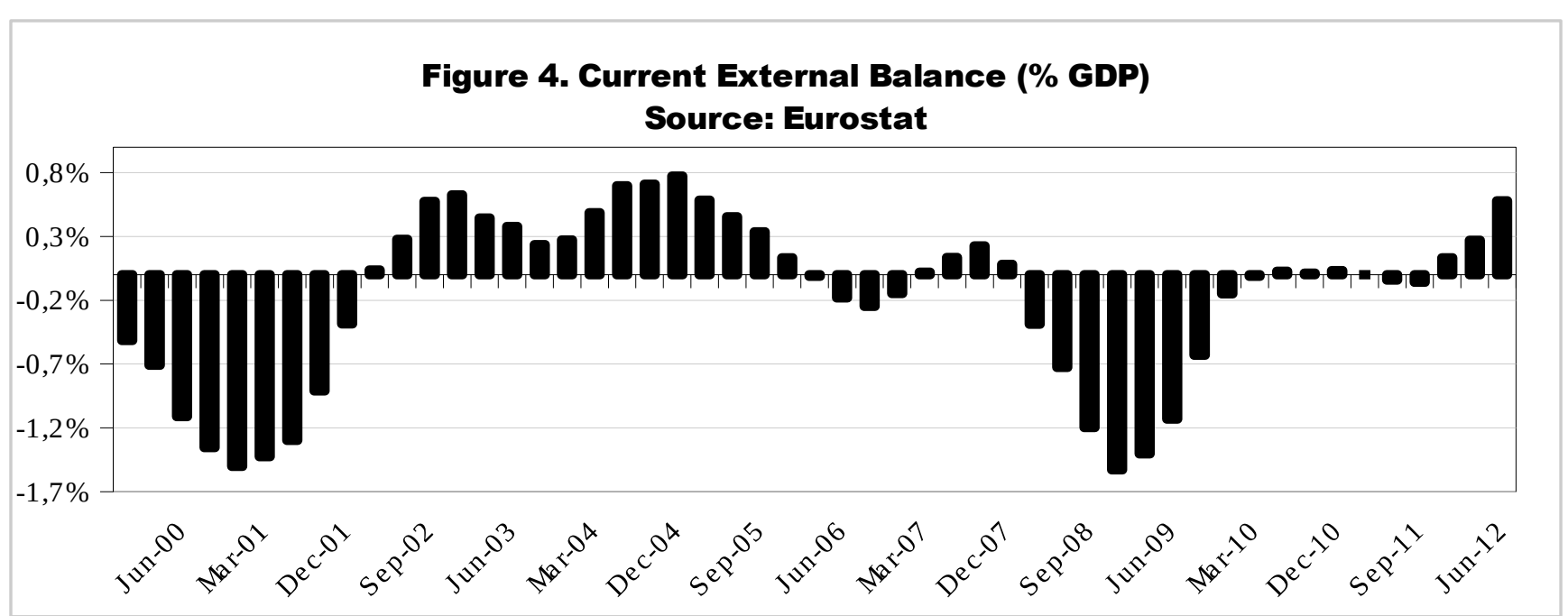


Third, another explanation can be found in the growing inequalities of household income distributions. As Timothy A. Wunder (2012) argued, unequal household incomes can generate disparities in consumption and savings behaviors. For the top earning households, increased incomes lead to increasing savings, while for lowest earners, it can lead to an increased debt as a result of trying to maintain consumption expenditures (Holt and Greenwood 2010; Wisman 2009). The financial exchanges between households that have increasing financing capacities and households that have increasing financing needs operate throughout the financial sector and result into an increasing domestic debt in both households and financial sectors. Although there is evidence of increasing inequalities in the Eurozone (OECD 2011), two main difficulties exist that challenge the validity of this explanation. First, the main Eurozone countries are still at a lower level of incomes inequalities than the USA is (OECD 2011). Secondly, in the absence of increasing incomes, the debt growth of the poorest households needs to be balanced by a growth in housing loans since they constitute the largest share in a household's debt. Table 1, however, shows that the growth of housing loans in the Eurozone is not sufficient to explain the growth of its domestic debt. Thus, if the American subprime mortgage crisis confirmed that increasing inequalities in household incomes may partially explain the growth of the U.S. domestic debt, it fails to provide a satisfactory explanation for the Eurozone debt growth.

Once investment expenditures, external imbalances and increasing inequalities are ruled out, only one explanation remains. The increase in the Eurozone domestic debt, does not rest on a growth in the value of the Eurozone economic activities, or in its productive assets. It is not due to a significant change in the households' behavior, or in an external demand for European securities. Therefore, the explanation for the Eurozone debt growth rests either on an increase in the financial leverage or on an artificial increase of the asset stocks value in the balance sheets of the European economic agents, which also means an increase of the effective leverage.

If this statement is correct, the growth of the Eurozone domestic debt would be almost exclusively due to a change in the behavior of the financial sector agents rather than of the productive sectors. That is, more loans were granted for each unit of real value. If the interest rates were constant, this change would have rapidly led to bankruptcy. The more loans there were, the more interest revenues there would have been, and the more difficult it would have been for economic agents to face their financial liabilities. However, as Figure 5 illustrates, the interest revenues did not broadly increase in the Eurozone since 1999. The explanation then is in the European decrease in interest rates over the same period of time. Figure 6 compares the ratio between interest revenues and domestic debt of the Eurozone and the European Central Bank (ECB) refinancing main interest rates. It appears that the decreasing ECB interest rates, following 1999, have reduced the amount of interests a loan can generate. 

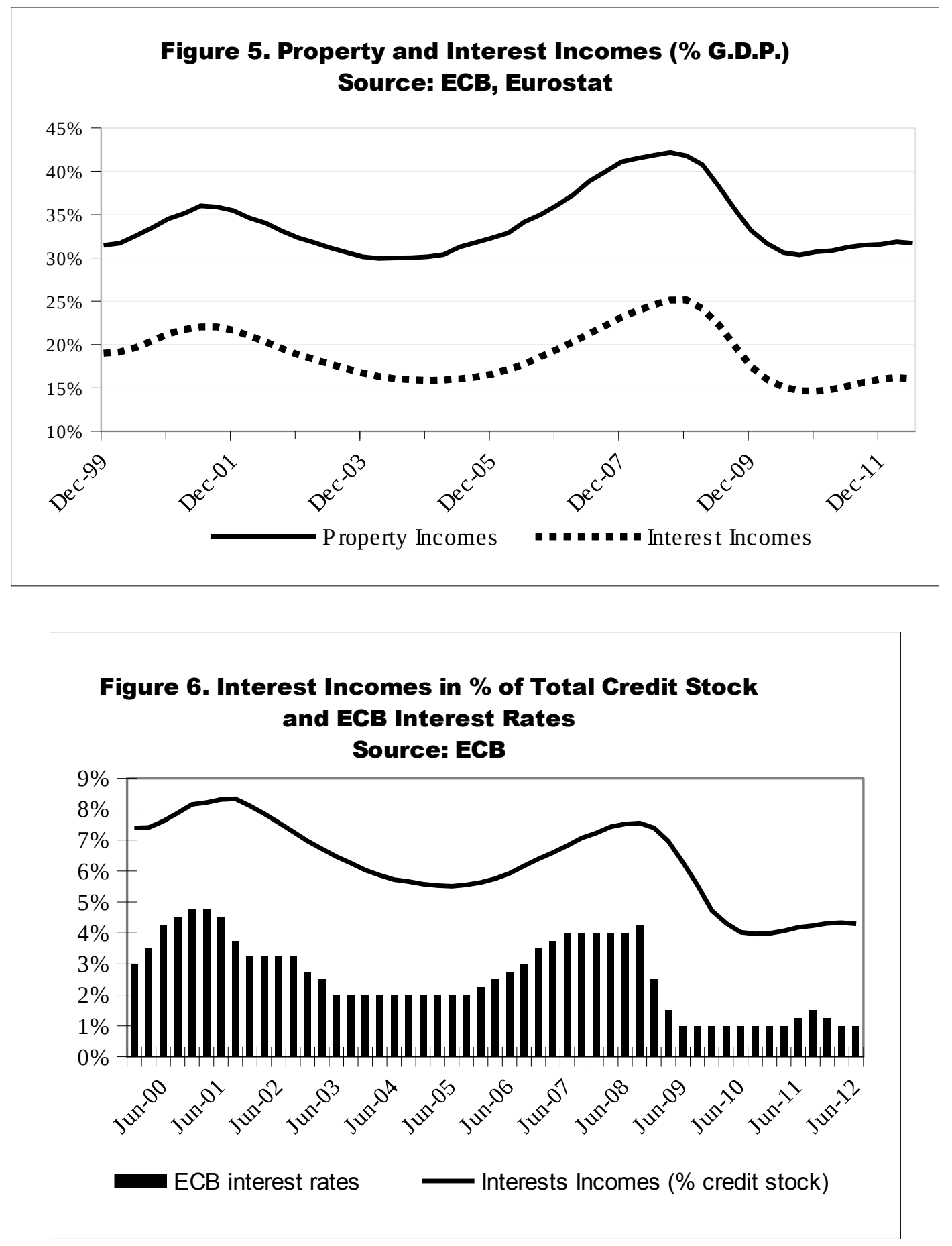

Figure 6 then provides a new explanation of the Eurozone economic situation. In order to offset the decrease of their revenues due to lower interest rates, the credit institutions in the Eurozone had to increase the amount of their loans. This was made possible by the financial deregulation process and the lack of real supervision from public authorities. Because interest rates are today at their lowest level, the outstanding amount of the Eurozone private debt is not an urgent issue. However, one can 
expect this debt to become an issue in the near future, especially if the Eurozone enters into a new economic recession.

\section{Conclusion: Why a Public Debt Restructuring Can Solve a Private Debt Issue}

The explanations for the Eurozone crisis differ among economists. On one hand, Alan Krugman (2012) argues that the main problem of the Eurozone does not rest on its public debts as European public opinions maintain. The case of the Spanish and Irish economies demonstrates that the public debt is more the consequence than the cause of the Eurozone crisis. On the other hand, the International Monetary Fund (IMF), the ECB and the European Commission contend that the main cause for the European economic situation lies in internal trade imbalances due to Southern Europe's lack of competitiveness.

In this paper, I tried to draw a different perspective on the Eurozone crisis. It was shown that although European and American economies differ, the evolution of their domestic private debts over the recent years is very similar. However, if the evolution of the American debt can be explained by external imbalances, the housing bubble, and high income inequalities, the evolution of the European private debt is much more difficult to explain. My assumption is that the Eurozone crisis is the result of a financial bubble, generated by the behavior of credit institutions that needed to offset the structural decline of their interest revenues by increasing the amount of granted loans. Because no economic real value can be found as a counterpart for these loans, I come to the conclusion that the main issue for European authorities to deal is the way to manage this private debt if economic growth continues to decline.

Figure 7 shows the ratio between the Eurozone domestic debt and net worth as it is estimated by the ECB. This ratio tends to get close to one hundred percent. Thus, if the Eurozone was a private firm, it would not be far from bankruptcy

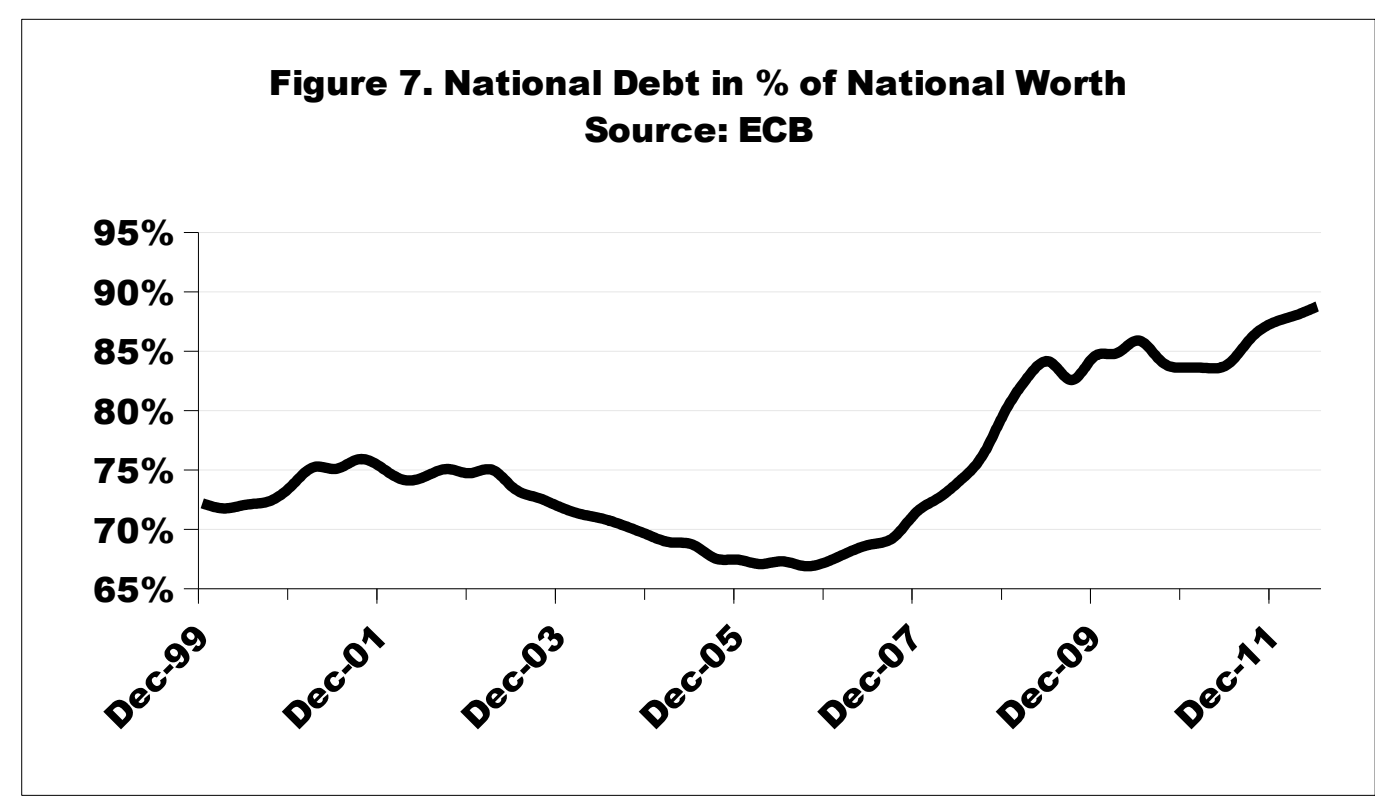


This situation can last for as long as interest rates stay low, there is no significant bankruptcy to generate panic in the financial sector, or the Eurozone is not confronted by another "Great Recession" crisis. In the long run, however, it will be necessary for the European private debt to return to a lower level.

This outcome can be achieved in one of three ways: First, bankruptcies in the private sector (financial and non-financial corporations, households, etc.) generate a decrease in the amount of private debts. In order to sustain economic activity, the public sector will have to increase its expenditures and debt. This is the way the USA is trying to solve its debt issues. However, this is difficult to implement since the Eurozone lacks a real federal budget and a political willingness to increase public expenditures. Second, inflation can cause the global debt to diminish. However, it is hard to see how inflation could appear since the actual European policies are mostly deflation oriented. For example the pro-competitive policies tend to reduce wages and product prices at the same time. Third, the last possible way to achieve the reduction of European debts would be through a public debt restructuring. Although the European public debt represents only a minor part of the Eurozone total domestic debt, these assets are used by the financial sector as risk-free assets that help them borrow from the central bank and lend to the private sector at high interest rates. ${ }^{2}$ For this reason, restructuring the public debts is not only a way to solve the European public debt issues, but also a means to decreasing the potential leverage of financial institutions.

As Fréderic Lordon (2011) wrote, one of the main paradoxes of the modern financial capitalism is its ability to make every economic sector run into excessive debt. In fact, this seems to be the most important common point between the American and Eurozone debt structure. Both economies are following the same track, led by the financial sector. The way the debts of the financial sectors are growing is almost a perfect reflection of the way the domestic debts are growing in both economies. If this assumption is confirmed, then the easiest way to solve debt issues on both sides of the Atlantic Ocean would be to restrain the financial sector's blind forces. For the Eurozone, I believe that the simplest way to accomplish this task if by organizing a global restructuration of the European public debts.

\section{Notes}

1. The Treaty on Stability, Coordination and Governance in the Economic and Monetary Union, also called the European Fiscal Compact, is the latest judiciary attempt to enforce the reduction of public deficits in the Eurozone. It enters into force on January 1, 2013.

2. This use of public debt securities is an unexpected outcome of the Basel Rules. Monetary financial institutions need to keep a proportion of the risk-free assets in order to maximize their leverage. This is the reason why they still buy public securities at negative interest rates. 


\section{References}

Caballero, Ricardo J. and Arvind Krishnamurthy. "Global Imbalances and Financial Fragility." American Economic Review 99, 2 (2009): 584-588.

European Central Bank. Statistical Data Warehouse. December 2012. Available at http://sdw.ecb.europa.eu. Acceessed December 12-15, 2012.

Federal Reserve. "Flow of Funds Accounts of the United States." Federal Reserve statistical release. 6 December 2012.

Guttman, Robert and Dominique Plihon. "Consumer Debt and Financial Fragility." International Journal of Applied Economics 24, 3 (2010): 269-283.

Holt, Richard P.F. and Daphne T. Greenwood. "Negative Trickle-Down and the Financial Crisis of 2008." Journal of Economic Issues 46, 2 (2012): 364-370.

Krugman, Alan. "Europe's Economic Suicide." The New York Time, April 15, 2012.

Palley, Thomas I. "America's Exhausted Paradigm: Macroeconomic Causes of the Financial Crisis and Great Recession." Working Paper, No.02/2009 (2009).

Liang, Yang. "Global Imbalances and Financial Crisis: Financial Globalization as a Common Cause." Journal of Economic Issues 46, 2 (2012): 353-362.

Lordon, Frédéric. "Le commencement de la fin." Le Monde Diplomatique, August 2011.

OECD "Divided We Stand: Why Inequalities Keep Rising: An Overview of Growing Income Inequalities in OECD Countries: Main Findings." OECD, 2011. Also available at www.oecd.org/els/soc/49499779.pdf.

Rosser, J. Barkley Jr., Marina V. Rosser and Mauro Gallegali. "A Minsky-Kindleberg Perspective on the Financial Crisis." Journal of Economic Issues 46, 2 (2012): 449-458.

Wisman, Jon D. "Households Savings, Class Identity, and Conspicuous Consumption." Journal of Economic Issues 43, 1 (2009): 89-114.

Wunder, Timothy A. "Income Distribution and Consumption Driven Growth: How Consumption Behaviors of the Top Income Quintiles Help to Explain the Economy." Journal of Economic Issues 46, 1 (2012): 171-191. 